\title{
Determinants of customer satisfaction in online grocery shopping
}

\author{
Imran Ali ${ }^{\mathrm{a}}$ and Mohammad Naushad ${ }^{b^{*}}$
}

${ }^{a}$ Assistant Professor, Noida Institute of Engineering and Technology, Greater Noida, India

${ }^{b}$ Assistant Professor, College of Business Administration, Prince Sattam Bin Abdulaziz University, Alkharj, Saudi Arabia

CHRON I C L E

Article history:

Received: March 21, 2021

Received in revised format: April

25,2021

Accepted: May 3, 2021

Available online: May 3, 2021

Keywords:

Convenience

Value

Risk

Product Quality

Service Quality

Customer Satisfaction

\section{Introduction}

Groceries have been bought from conventional supermarkets, where shoppers may inspect the product's content before buying it. Customers deserve to know if the materials are of high quality. They had enough time to study the product's consistency and pricing. However, consumers' behavior has changed over the last few years. During the COVID-19, the government has declared that people can remain at home and buy necessities. Customers used to fear leaving their homes. Customers were preferably likely to buy essentials from home only. Several companies have expanded tremendously and are meeting the most significant amount of demand across online platforms. The demand for food products has skyrocketed on online marketplaces. Consumers have responded positively to BigBasket, Grofers, and Amazon's online deals and promotions. Customers are likely to begin purchasing groceries digitally. Low rates, favorable government policy, timely distribution, and internet penetration are factors driving the development of the online grocery industry. Customers are increasingly turning to e-grocery stores to buy necessities. Companies are spending aggressively to make the supply chain more competitive and capable of meeting consumer demand efficiently, recognizing the online grocery industry's promise. Recently, the Government of India urged Indian firms and multinational corporations (MNCs) to invest in cold storage capacity and logistics. However, the e-commerce industry is still in its infancy (Ramus \& Nielsun, 2005), but it is predicted to expand at an unprecedented pace in the future (Melis et al., 2016). This business opportunity represents India's food and grocery market's digital transformation. Customers have the choice of purchasing supermarket products from either online or offline shops. Several choices resulted in many improvements in consumer purchasing behavior (Teller et al., 2016). They like to do their grocery shopping online. Therefore, the present study delves into factors that motivate shoppers to buy groceries from online retailers rather than conventional stores. Moreover, it aims to investigate the factors that influence consumer satisfaction with e-grocery shopping. The study is characterized by the following goals and objectives: i.e. (i). To identify the causes of switching online for grocery buying (ii).

* Corresponding author

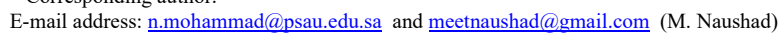

(C) 2021 by the authors; licensee Growing Science, Canada. doi: $10.5267 /$ j.ijdns.2021.5.005 
To determine the factors affecting the satisfaction of online grocery shoppers. (iii). To suggest strategies to online grocery retailers to improve the satisfaction of online grocery shoppers.

The article is structured in such a manner that the following segment discusses the literature review in order to investigate the research gap. The subsequent section explains the methodology used in the article. The next segment goes through the results obtained by using the analytical method. The final section of the paper addresses the managerial implications and concludes the article.

\section{Literature Review}

\subsection{Meaning of Customer's Satisfaction}

Customer satisfaction has long been used to assess a company's performance or failure. Customer satisfaction affects consumers' perceptions of society, competitors, and customers (Barsky \& Labagh, 1992). Customer retention has a long-term effect on operating performance and customer engagement in a retail store (Oliver, 1997). Several empirical studies on consumer satisfaction have been conducted, but there is no definitive concept of customer satisfaction in an absolute term as of yet. Few researchers (Cardozo, 1965; Oliver, 1977; Giese \& Cote, 2000) described consumer satisfaction as a sense of wellbeing following the use of a specific product. Furthermore, satisfaction is measured after purchasing a specific brand or product. The benefits consumers determine customer satisfaction to obtain after purchasing and enjoying a specific product. Customers do not always shop for that very same thing online for the same purpose. As a consequence, the variables that affect consumer loyalty in online grocery shopping can vary. Customers' expectations may vary (Tauber, 1972). Some consumers may be looking for high-quality products, and others may always choose to buy them. On the other hand, there are customers seeking recreational experiences in addition to shopping. To improve their consumers' shopping experiences, retailers must focus on such aspects. Retailers like to understand what is behind their customers' loyalty and dissatisfaction. Satisfied consumers are the organization's brand ambassadors, speaking positively of the company and recommending the retailers and brand to their friends.

\subsection{Perceived Convenience}

Convenience refers to the ease of purchasing the products. Customers prefer to buy seamlessly and without making extra efforts. Customers want to save time and cost. Online shopping makes this possible by availing multiple products at one click. Searching for prices and evaluating the competitors' products is relatively easy and straightforward on digital platforms. On the other hand, it is complex to challenge multiple products at multiple locations (Aylott \& Mitchell, 1998; Cassill et al., 1997). Many researchers have viewed convenience as less time and effort required for shopping. Customers have a wider choice for selecting products and customers can make payments either in cash or digitally. Customers can place orders at any point in time and can utilize their time optimally. Convenience refers to ease of purchasing the products. Customers prefer to buy seamlessly and without making extra efforts. Customers want to save time and cost. Online shopping makes this possible by availing multiple products at one click. Searching for prices and evaluating the competitors' products is relatively easy and straightforward on digital platforms. On the other hand, it is challenging to examine multiple products at multiple locations (Aylott \& Mitchell, 1998; Cassill et al., 1997). Many researchers have viewed convenience as less time and effort required for shopping. Customers have a wider choice for selecting products and customers can make payments either in cash or digitally. Customers can place orders at any point in time and can utilize their time optimally. Therefore, to check the impact of perceived convenience on customer satisfaction, the following hypothesis can be framed.

\section{$\mathbf{H}_{1}$ : Perceived Convenience is positively associated with Customer Satisfaction in e-grocery shopping.}

\subsection{Perceived Service Quality}

Service Quality refers to the standardization of services by a firm for its customers. Quality of services is an essential factor influencing the customer's satisfaction while shopping online. Online grocery stores offer various services to keep customers loyal and stay with the store for a long time (Parasuraman et al., 1988; Tsoukatos \& Rand, 2006; Turel et al., 2007). Service quality is confirmed when it fulfills the customers' expectations. Service quality should not fall short of customers' expectations (Chakrabarty \& Tan, 2007). Quality of services leave a long-lasting impact on the customers and make the services more satisfied and loyal to the retail stores. As a whole, the following hypothesis may be formulated to test the effect of perceived service quality on customer satisfaction.

\section{H2: Perceived Service Quality is positively associated with Customer Satisfaction in e-grocery shopping.}

\subsection{Perceived Value}

Value refers to the benefits received by the customers compared to the cost paid by the customers. Value is created when benefits are more than the customers' sacrifices (Heskett, 1977). However, customers are dissatisfied if they have to pay more than their benefits from a particular product. This is confirmed by various research studies that customers' satisfaction is more 
dependent on the benefits they received rather than the sacrifices they made to buy the product (Sirohi et al., 1998). Researchers have viewed perceived value as the ratio of product quality and product prices. The following hypothesis may be used to test the effect of perceived value on consumer satisfaction.

\section{H3: Perceived Value is positively associated with Customer Satisfaction in e-grocery shopping.}

\subsection{Perceived Product Quality}

Product quality enhances consumer loyalty and allows consumers more loyal to a brand. Customers are ecstatic as they see high-quality goods at low costs (Helgesen, 2006). Customers' loyalty is influenced not just by costs and service level but also by the product's quality. Product quality is one of the most important aspects influencing a customer's store selection and purchasing decision. Product quality guarantees consumer retention and commitment to a company (Baltas \& Papastathopoulou, 2003). The following hypothesis may be used to see whether perceived product quality affects customer satisfaction.

\section{H4: Perceived Product Quality is positively associated with Customer Satisfaction in e-grocery shopping.}

\subsection{Perceived Risk}

Perceived risk refers to the degree of risk involved in a business transaction. Customers do not want to buy a product if they perceive that there is some degree of risk. This is truer regarding online transactions, where all transactions are impersonal and driven by technology (Bart et al., 2005; Yang et al., 2015). Few research studies have outlined that customers are not very keen on buying the product online because they are apprehensive about disclosing personal information, and a firm might share their confidential information with any other organization. Various research studies have confirmed that customers will be inclined towards online shopping once they are sure about their personal information security (Bhatnagar et al., 2000; Black et al., 2002). Customers are also concerned about the product's performance risk. Customers are apprehensive about the product's quality and whether the product will fulfill said promises. As a result, the following hypothesis may be used to see how customer satisfaction is affected by perceived risk.

\section{Hs: Perceived Risk is negatively associated with Customer Satisfaction in e-grocery shopping.}

\subsection{Value for Time}

Many research studies have confirmed that customers have become more concerned about time. Customers are willing to perform multiple tasks in a short time. Customers need the availability of different products in one place to not have to visit multiple stores. Customers perceive that available time is insufficient to meet all their needs, so they want to utilize their time more optimally (Pan \& Zinkhan, 2006). Retailers must ensure that customers' waiting time within the store must be minimum to save customers' time and employees' time. This will improve customers' satisfaction and loyalty towards the organization (Grewal et al., 2003). Finally, the following hypothesis may be used to see whether customer satisfaction is affected by value for time.

H6: Value for Time is positively associated with Customer Satisfaction in e-grocery shopping.

\subsection{Hypotheses Model}

Six hypotheses were formulated to meet the goals of the present research and fill a gap in the literature. This study's broader aim is to figure out what makes consumers satisfied as they shop for groceries online. Using the existing literature, we defined six distinct components discussed above. To achieve the current study's aim of testing the specified hypothesis, the model can be expressed as shown in Fig. 1.

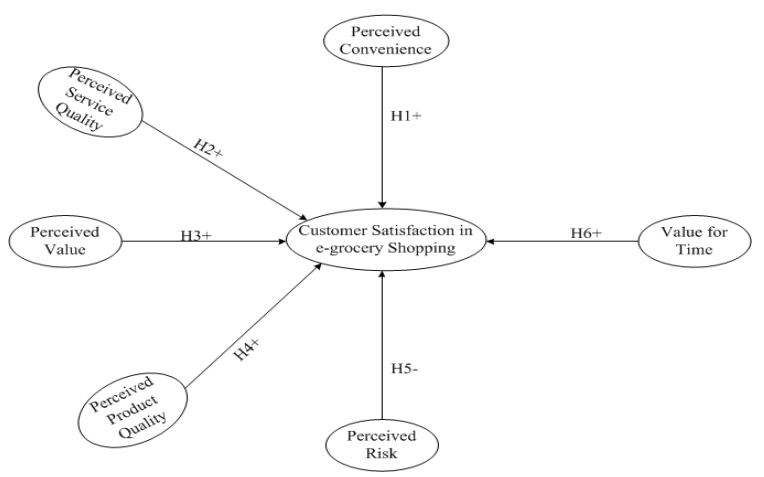

Fig. 1. Research Framework 


\section{Research Methodology}

The purpose of this study is to determine the factors that influence online grocery shopping. Between August 2020 and January 2021, data for this analysis were collected in Delhi and the National Capital Region (NCR) of Delhi. Since Delhi and NCR have the maximum prevalence for online grocery shopping, any research relating to online shopping should be conducted in Delhi and NCR. Respondents are readily accessible, and their input is helpful. Customers who have ordered supermarket products online and are over 18 years are the intended subjects for this study. An online survey was used to gather data. The questionnaires were sent to the respondents via email, Facebook, WhatsApp groups, etc. A total of 500 questionnaires were distributed, with 462 of them being considered for the final analysis. The questionnaire is designed with a five-point Likert scale, with 5 suggesting strong agreement and 1 indicating strong disagreement. There are two parts to the questionnaire. The first section of the questionnaire includes demographic questions for the users. The second section of the questionnaire includes queries about the structures chosen for the current analysis. To gather data for the current analysis, a convenient sampling method was used. Several statistical methods, including Exploratory Factor Analysis (EFA) and Confirmatory Factors Analysis, were used to evaluate the results. The data was analyzed using IBM SPSS 23 and IBM AMOS 23.

\section{Data analysis and results}

\subsection{Demographic Profile of Respondents}

The demographic characteristics of respondents are seen in Fig. 2. According to the results, 34.63 percent of respondents are between the ages of 18 and 30. This means that young shoppers are more motivated to purchase food products from online retailers than old-age consumers. Because young consumers have easy access to cell phones and mobile internet, they can conveniently shop online. In contrast, 8.66 percent of those surveyed are between the ages of 51 and 60 . This demonstrates that old-aged consumers do not prefer to order digitally. Nonetheless, they like to do their grocery shopping in person.

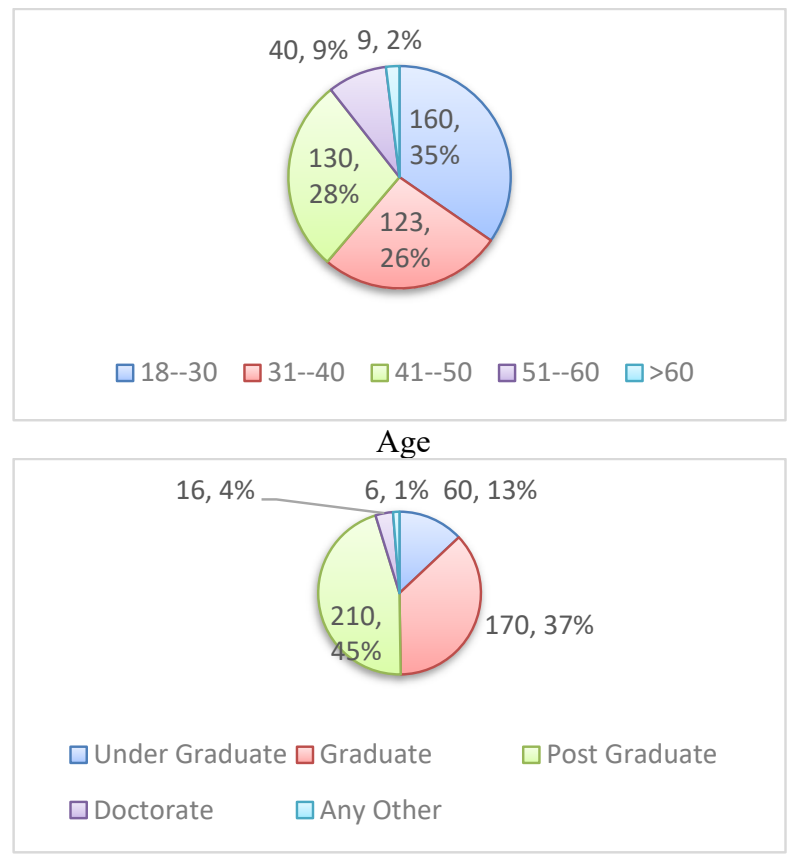

Educational background

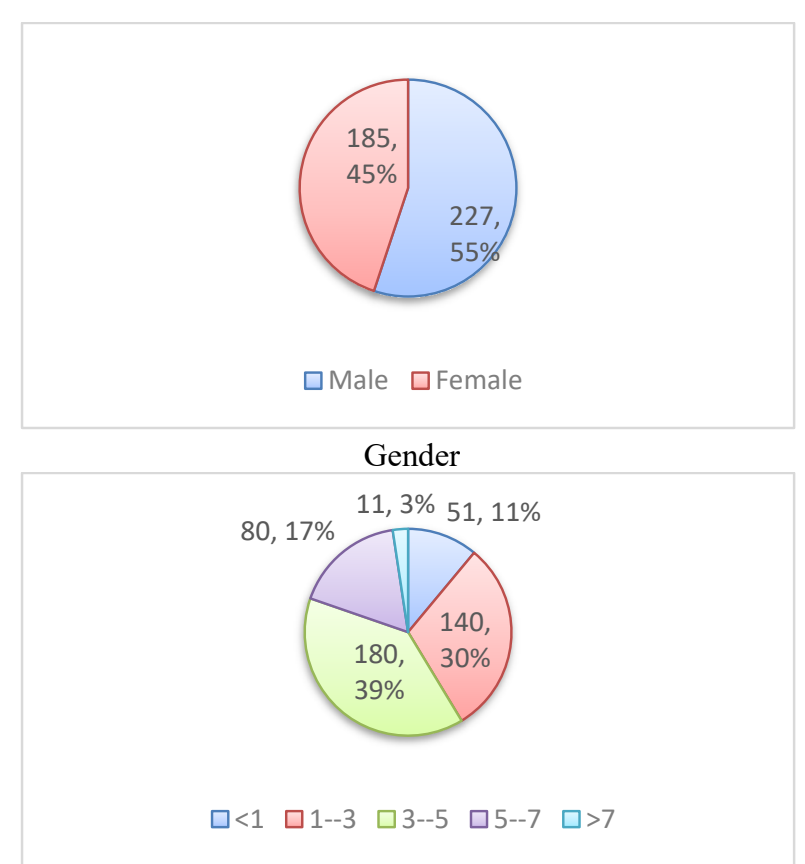

Annual Income (×Lakh)

Fig. 2. Respondents Profiles

\subsection{Exploratory Factor Analysis (EFA) and Confirmatory Factor Analysis (CFA)}

Exploratory factor analysis is part of multivariate analysis. Exploratory factor analysis is used to reduce the large set of data and find the underlying relationship between measured variables. In this study, there are 34 variable items, and seven constructs remained for further analysis. A Kaiser-Meyer-Olkin (KMO) test measures the adequacy of data. Whether the data is adequate to measure, what research is intended to measure? KMO value must be close to one. However, a KMO value of more than .50 is also acceptable. For the present study, the KMO value is .851, which is more than the target value of .05. On the other hand, Bartlett's Test of Sphericity shows that the p-value is less than .005 , which is acceptable. Both KMO and Bartlett's Test of Sphericity indicates that factor analysis is appropriate with the present data, and further analysis can be performed. Loadings of all the factors must be greater than .05 (Hair, 1998, 2010). After performing exploratory factor analysis, confirmatory factor analysis was performed to obtain the research model's overall validity and reliability. The validity of the factors is essential to measure the overall validity of the research model. Each construct's value in the research model 
must be greater than .07 (Nunnally, 1978). In his study, all 34 variable items' total reliability is .893, which is much higher than the set threshold. Further, the value of the average variance extracted must be greater than .05 .

Table 1

Construct Validity and Reliability

\begin{tabular}{|c|c|c|c|c|}
\hline Variable & Indicator & Loading & AVE & CR \\
\hline \multirow{5}{*}{ PERCEIVED CONVENIENCE } & $\mathrm{PC} 1$ & .739 & \multirow{5}{*}{0.628} & \multirow{5}{*}{0.894} \\
\hline & $\mathrm{PC} 2$ & .876 & & \\
\hline & $\mathrm{PC} 3$ & .797 & & \\
\hline & PC4 & .735 & & \\
\hline & PC5 & .806 & & \\
\hline \multirow{5}{*}{ PERCEIVED VALUE } & PV1 & .846 & \multirow{5}{*}{0.754} & \multirow{5}{*}{0.939} \\
\hline & PV2 & .871 & & \\
\hline & PV3 & .878 & & \\
\hline & PV4 & .896 & & \\
\hline & PV5 & .850 & & \\
\hline \multirow{5}{*}{ PERCEIVED SERVICE QUALITY } & PSQ1 & .715 & \multirow{5}{*}{0.644} & \multirow{5}{*}{0.900} \\
\hline & PSQ2 & .831 & & \\
\hline & PSQ3 & .826 & & \\
\hline & PSQ4 & .841 & & \\
\hline & PSQ5 & .796 & & \\
\hline \multirow{5}{*}{ PERCEIVED PRODUCT QUALITY } & PPQ1 & .800 & \multirow{5}{*}{0.712} & \multirow{5}{*}{0.925} \\
\hline & PPQ2 & .871 & & \\
\hline & PPQ3 & .905 & & \\
\hline & PPQ4 & .875 & & \\
\hline & PPQ5 & .762 & & \\
\hline \multirow{5}{*}{ RISK FACTOR } & RF1 & .802 & \multirow{5}{*}{0.754} & \multirow{5}{*}{0.939} \\
\hline & RF2 & .863 & & \\
\hline & RF3 & .884 & & \\
\hline & RF4 & .926 & & \\
\hline & RF5 & .863 & & \\
\hline \multirow{4}{*}{ VALUE FOR TIME } & VFT1 & .897 & \multirow{4}{*}{0.810} & \multirow{4}{*}{0.945} \\
\hline & VFT2 & .915 & & \\
\hline & VFT3 & .891 & & \\
\hline & VFT4 & .896 & & \\
\hline \multirow{5}{*}{ CUSTOMER SATISFACTION } & CS1 & .826 & \multirow{5}{*}{0.700} & \multirow{5}{*}{0.921} \\
\hline & CS2 & .869 & & \\
\hline & CS3 & .806 & & \\
\hline & CS4 & .831 & & \\
\hline & CS5 & .851 & & \\
\hline
\end{tabular}

Convergent validity measures the validity of a construct. Each item of a construct must produce the same result. The convergent validity of the model is determined when AVE's value is greater than .05 (Molina et al., 2007). However, some researchers accept AVE, even if it is less than .05 with one condition that Cronbach alpha and composite reliability values are more than .07 (Fornell, 1992; Fornell et al., 1996; Fornell \& Wernerfelt, 1987). In Table 1, all the constructs have an average variance of more than 0.5 , which is higher than the set threshold. Further, the value of composite reliability for all the constructs is more than 0.7 .

\subsection{Discriminant Validity}

Discriminant validity determines that each construct must be different from the other constructs (Hair et al., 2016; Hulland, 1999). Discriminant validity is attained by comparing AVE's square root with the correlation of the latent variables (Fornell, 1992; Fornell et al., 1996; Fornell \& Wernerfelt, 1987). The value of AVE's squared root needs to be higher than the correlation of other latent variables (Hair et al., 1998, 2010). Diagonal values in the following table represent the square root of average variance extracted. The value of the square root of average variance extracted must be greater than the correlation values of construct, hence established discriminant validity. Table 2 presents the results of discriminant validity.

Table 2

Discriminant Validity

\begin{tabular}{|c|c|c|c|c|c|c|c|}
\hline Constructs & PC & PV & PSQ & PPQ & RF & VFT & CS \\
\hline PC & .394 & & & & & & \\
\hline PV & 0.327 & 0.569 & & & & & \\
\hline PSQ & 0.493 & 0.492 & 0.415 & & & & \\
\hline PPQ & -.049 & -.064 & -.004 & 0.507 & & & \\
\hline RF & .066 & -.004 & 0.097 & 0.41 & 0.569 & & \\
\hline VFT & -.005 & .048 & .065 & 0.23 & 0.424 & 0.656 & \\
\hline CS & .068 & -.026 & .002 & 0.449 & 0.349 & 0.262 & 0.490 \\
\hline
\end{tabular}


Model fitness refers to the overall fitness of the research model. Whether the model is capable enough to measure, what the model intends to measure. The fitness of the research model is checked against various parameters like Goodness of Fit Index (GFI), Adjusted Goodness of Fit Index (AGFI), Root Mean Square Error of Approximation (RMSEA), Normed Fit Index (NFI), Comparative Fit Index (CFI), Incremental Fit Index (IFI) and Tucker-Lewis Index (TLI). The measurement model of this study has all values as per the recommended value. The value of GFI is .821, RMSEA is .073, NFI is .877, CFI is .906, IFI is .906 and TLI is .895 . Table 3 presents the results of the model fit.

Table 3

Model Fit

\begin{tabular}{ccc}
\hline Absolute Fit Measure & Recommended Value & Model Value \\
\hline CMIN/DF & $<5.00$ & 3.799 \\
GFI & $>0.90$ & .821 \\
NFI & $>0.95$ & .877 \\
CFI & $>0.90$ & .906 \\
IFI & $>0.90$ & .906 \\
TLI & $>0.90$ & .895 \\
RMSEA & $<0.05$ & .073 \\
\hline
\end{tabular}

\subsection{Structural model}

After measuring the research model's fitness against various parameters, a structural model was established, and hypothesis testing was done using path analysis among the variables.

Table 4

Hypotheses Conclusion

\begin{tabular}{|c|c|c|c|c|c|c|c|c|}
\hline Hypothesis & \multicolumn{3}{|c|}{ Path } & Estimate & S.E. & C.R. & $\mathbf{P}$ & Status \\
\hline $\mathrm{H} 1$ & $\mathrm{CS}$ & $\leftarrow$ & $\mathrm{PC}$ & 0.109 & 0.043 & 2.549 & 0.011 & Accepted \\
\hline $\mathrm{H} 2$ & $\mathrm{CS}$ & $\leftarrow$ & $\mathrm{RF}$ & 0.155 & 0.042 & 3.704 & $* * *$ & Accepted \\
\hline $\mathrm{H} 3$ & $\mathrm{CS}$ & $\leftarrow$ & PV & -0.014 & 0.041 & -0.354 & 0.723 & Rejected \\
\hline $\mathrm{H} 4$ & $\mathrm{CS}$ & $\leftarrow$ & PPQ & 0.299 & 0.038 & 7.94 & $* * *$ & Accepted \\
\hline H5 & $\mathrm{CS}$ & $\leftarrow$ & PQS & -0.057 & 0.035 & -1.654 & 0.098 & Accepted \\
\hline H6 & $\mathrm{CS}$ & $\leftarrow$ & VFT & 0.156 & 0.043 & 3.582 & $* * *$ & Accepted \\
\hline
\end{tabular}

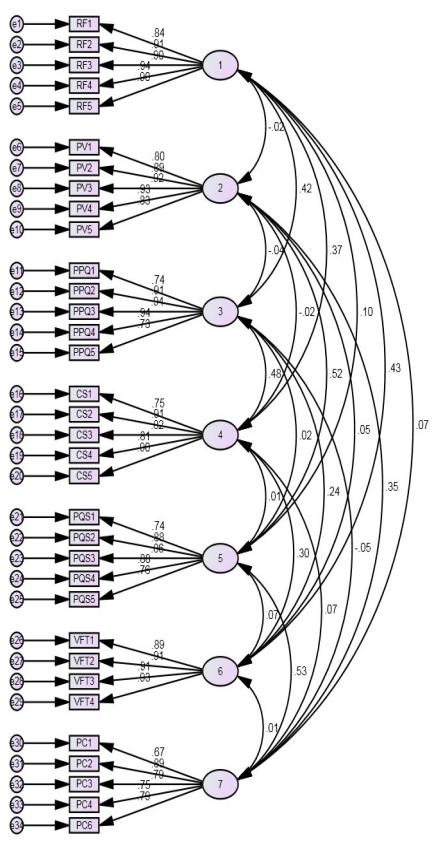

Fig. 2. Model Fit

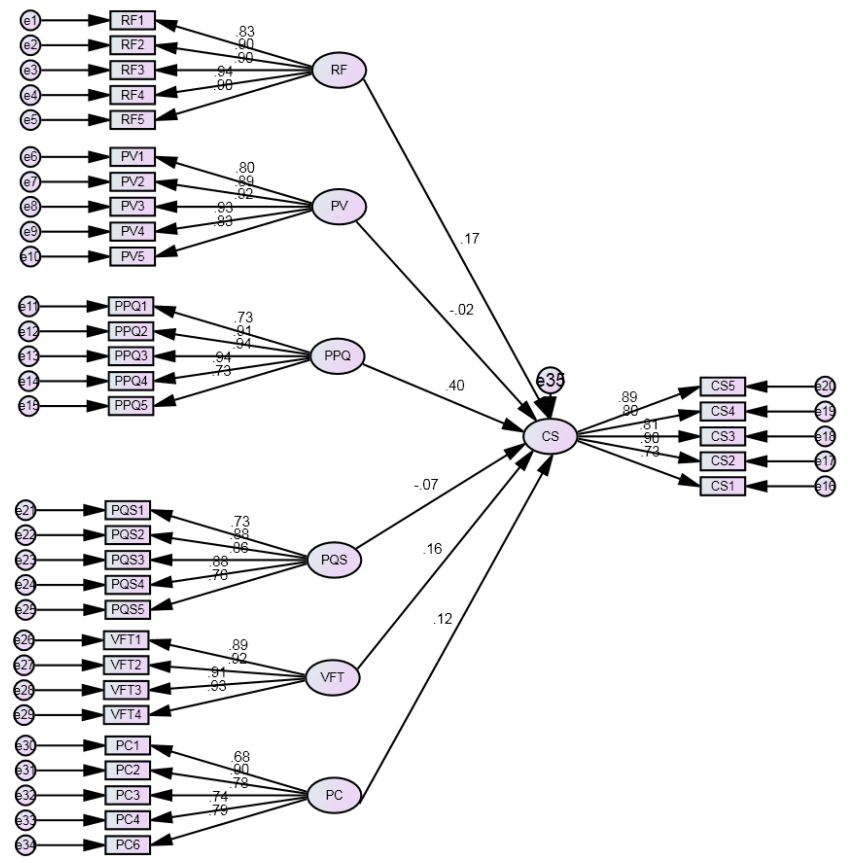

Fig. 3. Structural Model

\section{Discussion}

This study's primary objective is to determine the key factors influencing consumer satisfaction with online grocery shopping. This research included many independent variables such as perceived convenience, perceived value, perceived service quality, 
perceived product quality, perceived risk, and value for time. Their impact on customer satisfaction was evaluated. This study's findings are consistent with previous studies. However, certain findings differ from those of previous research. This study confirms that ease is related to consumer loyalty when shopping for groceries online. This means that grocery shoppers like to buy from their online shops without dealing with any hassles. This finding is consistent with previous study results (Aylott \& Mitchell, 1998). Customer happiness, on the other hand, is not favorably correlated with perceived value. This study's findings are not comparable to previous studies (Heskett, 1977). Furthermore, perceived product quality is one of the significant variables positively influencing customer satisfaction. This research further shows that perceived product quality influences customer satisfaction. Several previous studies have also indicated that product quality is related to consumer satisfaction (Baltas \& Papastathopoulou, 2003). Customer happiness is often favorably related to perceived risk. Previous scholars have validated similar results (Bart et al., 2005; Yang et al., 2015). Customers are less willing to purchase food digitally if they are not sure that their personal information would not be exchanged with anyone.

\section{Conclusion and Suggestions}

There are several factors affecting the customers' satisfaction positively in e-grocery shopping. This study has confirmed that perceived convenience, perceived value, perceived product quality, perceived risk, and value for time are positively associated with the customer's satisfaction. Grocery retailers have to ensure that customers feel secure while they are online. Many customers do not want to shop online because they think their financial information will be shared with others. Further, competition is likely to increase in online grocery shopping. Many new companies have entered into the business, and many more are likely to enter this business. Therefore, online grocery retailers must identify new methods to enhance customers' satisfaction. The findings of this study suggest various strategies to online grocery shoppers so that they can improve customers' satisfaction in online grocery shopping. One important thing that online grocery retailers have to ensure is convenience. Customers must experience a hassle-free shopping environment, and customers can easily find all the information on the company's website. Retailers need to ensure the safety of the client's data strictly and not be leaked or shared with other people in any way. This concern is more significant in online grocery shopping because everything is impersonal and driven by technology. Further, Product quality is the most influential determinant of customers' satisfaction and retailers could retain their customers for long if they offer quality products to their customers. This made the retailers brand image positive among the customers and competitors. Customers are highly concerned about the time they spend on shop products; they prefer to spend minimum time in retailers and searching for products. Payment options must be multiple and long waiting lines leave a negative impact on customers' satisfaction.

\section{References}

Aylott, R., \& Mitchell, V. W. (1998). An exploratory study of grocery shopping stressors. International Journal of Retail \& Distribution Management, 26(9), 362-373.

Baltas, G., \& Papastathopoulou, P. (2003). Shopper characteristics, product and store choice criteria: a survey in the Greek grocery sector. International Journal of Retail \& Distribution Management, 31(10), 498-507.

Barsky, J. D., \& Labagh, R. (1992). A strategy for customer satisfaction. Cornell Hotel and Restaurant Administration Quarterly, 33(5), 32-40.

Bart, Y., Shankar, V., Sultan, F., \& Urban, G. L. (2005). Are the drivers and role of online trust the same for all web sites and consumers? A large-scale exploratory empirical study. Journal of Marketing, 69(4), 133-152.

Bhatnagar, A., Misra, S., \& Rao, H.R. (2000). On risk, convenience and Internet shopping behaviour. Communication of the $A C M, 43,98-105$.

Cardozo, R. N. (1965). An experimental study of customer effort, expectation, and satisfaction. Journal of Marketing Research, 2(3), 244-249.Melis, K., Campo, K., Lamey, L., \& Breugelmans, E. (2016). A bigger slice of the multichannel grocery pie: when does consumers' online channel use expand retailers' share of wallet?. Journal of Retailing, 92(3), 268286.

Cassill, N. L., Thomas, J. B., \& Bailey, E. M. (1997). Consumers' definitions of apparel value: An investigation of department store shoppers. Journal of Fashion Marketing and Management: An International Journal, 1(4), 308-321.

Chakrabarty, A., \& Tan, K. C. (2007). The current state of six sigma application in services. Managing Service Quality: An International Journal, 17(2).

Fornell, C. (1992). A national customer satisfaction barometer: The Swedish experience. Journal of marketing, 56(1), 6-21.

Fornell, C., Johnson, M. D., Anderson, E. W., Cha, J., \& Bryant, B. E. (1996). The American customer satisfaction index: nature, purpose, and findings. Journal of Marketing, 60(4), 7-18.

Fornell, C., \& Wernerfelt, B. (1987). Defensive marketing strategy by customer complaint management: a theoretical analysis. Journal of Marketing Research, 24(4), 337-346.

Giese, J. L., \& Cote, J. A. (2000). Defining consumer satisfaction. Academy of Marketing Science Review, 1(1), 1-22.

Grewal, D., Baker, J., Levy, M., \& Voss, G. B. (2003). The effects of wait expectations and store atmosphere evaluations on patronage intentions in service-intensive retail stores. Journal of Retailing, 79(4), 259-268.

Hair, J. F., Anderson, R. E., Tatham, R. L., \& Black, W. C. (1998). Multivariate Data Analysis. Upper Saddle River, NJ: Prentice Hall. 
Hair, J. F., Anderson, R. E., Babin, B. J., \& Black, W. C. (2010). Multivariate data analysis: A global perspective. Upper Saddle River, NJ: Pearson.

Heskett, J. L. (1977). Logistics: essential to strategy. Harvard Business Review, 55(6), 85-96.

Helgesen, Ø. (2006). Are loyal customers profitable? Customer satisfaction, customer (action) loyalty and customer profitability at the individual level. Journal of Marketing Management, 22(3-4), 245-266.

Molina, L. M., Llorens-Montes, J., \& Ruiz-Moreno, A. (2007). Relationship between quality management practices and knowledge transfer. Journal of Operations Management, 25(3), 682-701.

Nunnally, J. C. (1978). An overview of psychological measurement. Clinical diagnosis of mental disorders, 97-146.

Oliver, R. L. (2000). Customer satisfaction with service. Handbook of services marketing and management, 247254.

Pan, Y., \& Zinkhan, G. M. (2006). Determinants of retail patronage: a meta-analytical perspective. Journal of retailing, 82(3), 229-243.

Parasuraman, A., Zeithaml, V.A., \& Berry, L.L. (1988). SERVQUAL: A Multi-Item Scale for Measuring Consumer Perceptions of Service Quality. Journal of Retailing, 64(Spring), 13-40.

Ramus, K., \& Nielsen, N. A. (2005). Online grocery retailing: what do consumers think?. Internet Research, 15(3), $335-352$.

Tauber, E. M. (1972). Marketing notes and communications: Why do people shop?. Journal of Marketing, 36(4), 46-49.

Teller, C., Alexander, A., \& Floh, A. (2016). The impact of competition and cooperation on the performance of a retail agglomeration and its stores. Industrial Marketing Management, 52, 6-17.

Turel, O., Serenko, A., \& Bontis, N. (2007). User acceptance of wireless short messaging services: Deconstructing perceived value. Information \& Management, 44(1), 63-73.

Tsoukatos, E., \& Rand, G. K. (2006). Path analysis of perceived service quality, satisfaction and loyalty in Greek insurance. Managing Service Quality: An International Journal, 16(5), 501-519.

Yang, Q., Pang, C., Liu, L., Yen, D. C., \& Tarn, J. M. (2015). Exploring consumer perceived risk and trust for online payments: An empirical study in China's younger generation. Computers in Human Behavior, 50, 9-24.

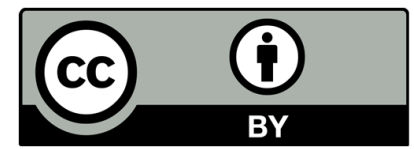

(C) 2021 by the authors; licensee Growing Science, Canada. This is an open access article distributed under the terms and conditions of the Creative Commons Attribution (CC-BY) license (http://creativecommons.org/licenses/by/4.0/). 